\title{
INVESTIGATION INTO ENERGY SAVINGS IN THE RENEWAL OF THE LIGHTING SYSTEM IN UNIVERSITY CAMPUS BUILDINGS
}

\begin{abstract}
Summary
This study shows the amount of energy savings to be achieved in electricity consumption if the current lighting system in the buildings of the Cumhuriyet University campus in Turkey is replaced with efficient lighting systems. In addition, environmental effects of energy savings are determined by calculating the amounts of $\mathrm{CO}_{2}, \mathrm{SO}_{2}, \mathrm{NO}_{\mathrm{X}}, \mathrm{CO}$ emissions. The Life Cycle Cost (LCC) analysis is used to determine energy costs and payback periods. The calculations reveal that the use of three alternative lighting systems would lead to a substantial reduction in electricity consumption ranging between $16.5 \%$ and $40.5 \%$, and that the payback periods of these alternative lighting systems vary between 1.9 and 5 years.
\end{abstract}

Key words: $\quad$ lighting; life cycle cost analysis; emission reduction; energy efficiency

\section{Introduction}

In addition to attempts made to meet energy needs of Turkey, the efficient use of current energy and attempts to save energy are also of great importance. The rapid increase in the consumption of electric energy versus the slow increase in the production of electric energy has put the issue of using electricity more efficiently on the agenda. To increase the efficient use of energy, to avoid waste, to ease the burden of energy costs on the economy, and to protect the environment, the Energy Efficiency Law (No. 5627) was enacted after it was published in the Official Gazette on May 2, 2007. Figure 1 shows electricity consumption estimated as a baseline scenario by the General Directorate of Turkish Electricity Transmission Corporation for a period of ten years. The electricity demand is estimated to be 376,785 GWh in 2023 [1]. By using a correct lighting system energy consumption costs can be reduced. In order to reduce electricity consumption for lighting purposes in public institutions, the use of energy-saving lamps has increased in Turkey in recent years as it has all over the world. The gap between electricity supply and demand in Turkey, the increase in expenditures on building power supplies and the perception of energy saving as a general policy constitute the main incentives for customers to choose these energy saving devices. Mahlia et al. investigated the amount of energy savings and payback periods that could be achieved by changing the lighting system at the University of Malaysia. The LCC decreased by $40 \%$ after all lamps were replaced with the T5 lighting system within 10 years [2]. In studies on efficient lighting conducted at the Stuttgart University [3], daylight measurements and simulations were performed for classrooms and computer labs, and electricity consumption was calculated. The analysis showed that the use of LED lamps reduced energy consumption by $34 \%$. 


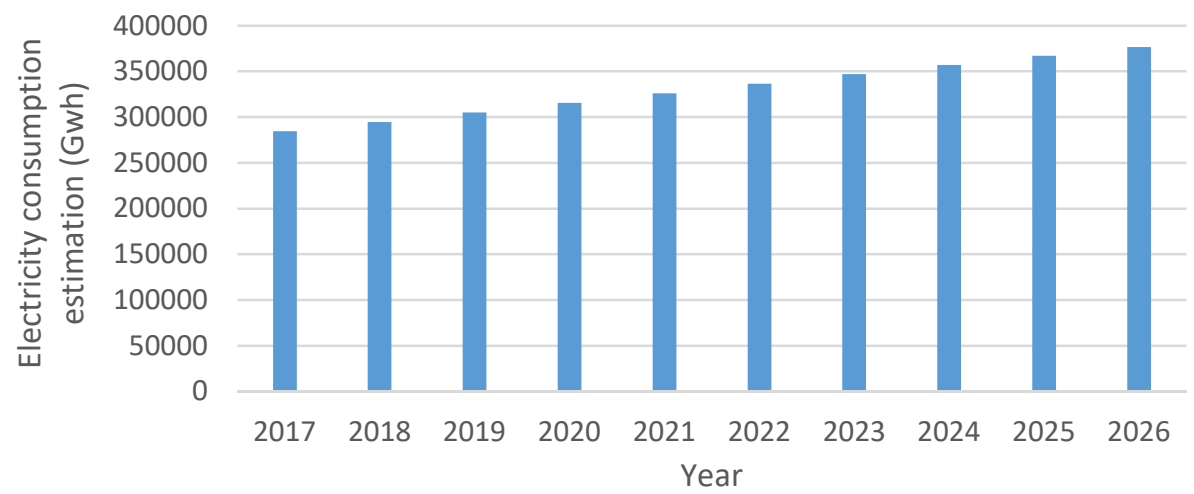

Fig. 1 Turkey's 2017-2026 gross electricity consumption estimation in the baseline scenario [1]

In a study conducted on another campus, energy gains and carbon dioxide emissions were calculated after $1.2 \mathrm{~m}$-long fluorescent lamps installed in the buildings were replaced with four different lighting systems [4]. The results showed that there was a $13.9 \%, 20.5 \%$, $24.4 \%$ and $64.9 \%$ decrease in energy consumption and a $10 \%$ decrease in $\mathrm{CO}_{2}$ emissions. It was observed that the hours during which the lighting system was on, the electricity prices, and the prices of the lamps and equipment significantly influenced the results. Jamaludin et al. studied bioclimatic design strategies and the performance characteristics of the electricity use in college buildings. They used the Energy Efficiency Index to measure the performance of electricity usage. The simulation results indicate that, with efficient use of electricity the average electricity use can be reduced to 24 to $34 \mathrm{kWh} / \mathrm{m}^{2} /$ year [5]. In 2011, Lam et al. used the life cycle cost method to analyze the replacement of general lighting lamps with energy saving light bulbs in two Honkong hotels. It was found that the payback period was about one year, and the obtained reduction in electricity consumption was $70 \%$. The reduction in $\mathrm{CO} 2$ emissions was $420 \mathrm{~kg}$ for the two hotels [6]. Preston et al. dealt with an economic analysis of the replacement by retrofitting three lighting systems commonly used in industrial applications. Recent pulse-start metal halide lamps and a range of T5 high output and T8 fluorescent lamp configurations were considered in the analysis. Savings, payback period, and net present value for many retrofit options, as well as the change in energy consumption, carbon footprint, and lumen output were calculated for each retrofit [7]. Soori et al. conducted a study on control strategy for energy efficient office lighting system design. They used a lighting control algorithm to increase energy efficiency [8]. Stansbury et al. investigated reduction in $\mathrm{SO}_{2}, \mathrm{NO}_{\mathrm{x}}, \mathrm{CO}_{2}$, and $\mathrm{CO}$ emissions and retrofitting the building with an energy-efficient lighting system. The results showed that significant reductions in utility bills as well as reductions in air emissions would result from a major conversion of a building if a more energy efficient lighting system were installed. Namely, the conversion of this large building would reduce $\mathrm{SO}_{2}$ emissions by 14.6 tons/yr. and $\mathrm{NO}_{\mathrm{x}}$ emissions by 6.3 tons/yr. [9].

In this study, decrease in electricity consumption, Life Cycle Cost (LCC) and payback period were calculated if different energy efficient lighting systems were installed in the buildings at the Cumhuriyet University.

\section{Lighting System}

Cumhuriyet University located on 11,000 decares ( 2,718 acres) of land is a large higher education institution comprising 11 faculties, four institutes, one state conservatory, six colleges, 14 vocational schools and one research hospital (Figure 2). In all classrooms, corridors and offices of the university fluorescent lamps are installed. They have a wide range of power, color and lifespan. Visible light in fluorescent lamps is produced by a mixture of three different phosphors in the inner wall of the lamp. 


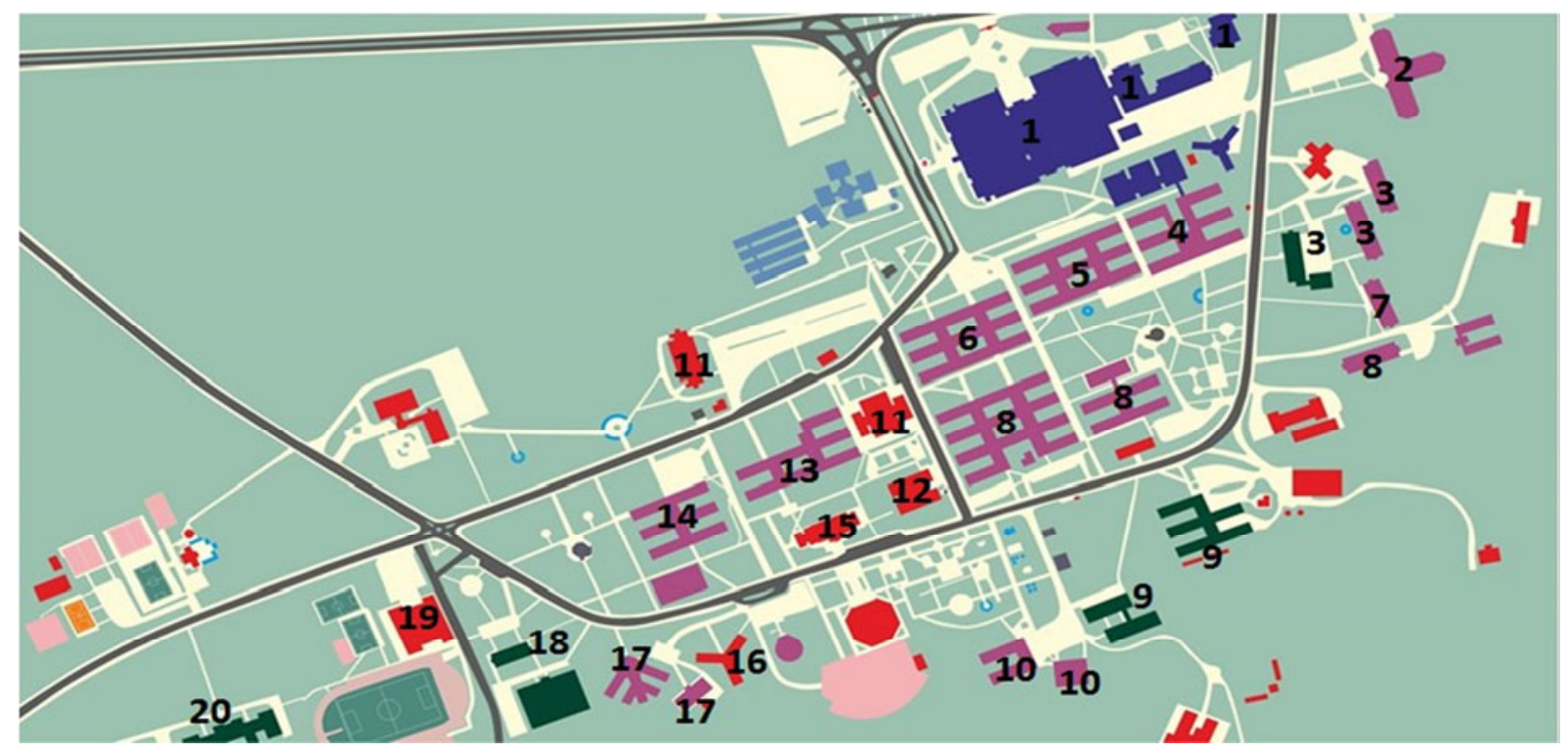

\begin{tabular}{llll}
\hline No & Faculty & No & Faculty \\
\hline 1 & Hospital & 11 & Refectory \\
2 & Faculty of Dentistry & 12 & Library \\
3 & Faculty of Health Sciences & 13 & Faculty of Science \\
4 & Faculty of Economics And & 14 & Faculty of Education \\
& Administrative Sciences & 15 & Lecture Hall \\
5 & Faculty of Medicine & 16 & Sciences and CUSEM \\
6 & Faculty of Letters & 17 & Faculty of Fine Arts \\
7 & Faculty of Technology & 18 & Physical Education and Sports \\
8 & Faculty of Engineering & 19 & C. Gym \\
9 & Faculty of Theology & 20 & School of Foreign Languages \\
10 & Vocational School & & \\
\hline
\end{tabular}

Fig. 2 Map of the Cumhuriyet University

UV radiation generated by the collision of electrons detached due to the discharge between the electrodes to the mercury atoms in the discharge tube is converted into visible radiation by the fluorescent substance in the inner wall of the tube. The lamps in the university buildings are T12-40W, T12-20W, T8-36W and T8-18W fluorescent lamps $0.6 \mathrm{~m}$ and $1.2 \mathrm{~m}$ in length. All lighting systems have coil ballasts. To replace the current lighting system for the purpose of energy saving, three different lighting systems (T8 electronic ballast, T5 and T8 LED) were considered. The new lamps were chosen to have the same collective light intensity values as the existing lamps in offices and classrooms. The specifications of lamps are shown in Table 1 and Table 2.

\subsection{Lighting Strategy 1}

The first option is to replace all lamps with T8-36 $\mathrm{W}$ and T8-18 $\mathrm{W}$ lamps using electronic ballasts instead of coil ballasts as this is the case in the current lighting system. By using an electronic ballast, T8 fluorescent lamps will work faster, consume less energy, and will not produce the flickering-related buzzing or humming sound. In addition, T8 lamps have a life span of 20,000 hours and they lose $20 \%$ of their light output during their lifetime. 


\subsection{Lighting Strategy 3}

The third alternative is to replace all lamps with LED T8-9 $\mathrm{W}$ and LED T8-18 W lamps and increase the number of current luminaires. Because the lumen output of LED T8 lamps is lower, more lamps will be used for each room to produce the lumen value equal to that produced by current lamps. LED lamps consume approximately $50 \%$ less electricity compared to standard fluorescents. LED T8 lamps have a life span of about 40,000 hours, which is longer than that of standard fluorescent lamps. LED lamps do not emit ultraviolet or infrared rays as do fluorescent lamps and they are environmentally friendly because they do not contain harmful gases, such as mercury vapor. In addition, LED lamps emit stable light, do not flicker, can be directly connected to the mains electricity and do not need a starter and ballast like fluorescent lamps.

Table 3 Number of lamps collected

\begin{tabular}{lcccc}
\hline FACULTY & $\mathbf{T 8}$ & $\mathbf{T 8}$ & $\mathbf{T 1 2}$ & $\mathbf{T 1 2}$ \\
$\mathbf{( 0 . 6} \mathbf{~ m})$ & $(\mathbf{1 . 2} \mathbf{~ m})$ & $(\mathbf{0 . 6} \mathbf{~ m})$ & $\mathbf{( 1 . 2 ~ \mathbf { ~ } )}$ \\
\hline Letters & 196 & 758 & 0 & 0 \\
Science & 106 & 448 & 24 & 1,058 \\
Cumhuriyet Higher Vocational & 478 & 915 & 88 & 416 \\
Health Sciences & 561 & 928 & 2 & 0 \\
Technology And Theology & 296 & 929 & 4 & 76 \\
Fine Arts & 166 & 806 & 0 & 0 \\
Education & 157 & 13 & 197 & 944 \\
Medicine & 420 & 940 & 0 & 0 \\
Economics And Administrative & 1,160 & 312 & 0 & 28 \\
Sciences & 274 & 226 & 0 & 32 \\
Physical Education And Sports & 0 & 274 & 172 & 98 \\
Gym & 840 & 408 & 60 & 778 \\
School Of Foreign Languages & 20 & 396 & 0 & 0 \\
Institutes And CUSEM & 364 & 50 & 0 & 0 \\
Pool & 10 & 28 & 60 & 606 \\
Library & 236 & 0 & 136 & 60 \\
Lecture Hall & 1,762 & 7,000 & 44 & 350 \\
Hospital & 749 & 2,134 & 559 & 914 \\
Engineering & 104 & 616 & 0 & 0 \\
Dentistry & 144 & 770 & 0 & 0 \\
Refectory & 8,043 & 17,951 & 1,346 & 5,360 \\
Total: 32,700 & & & & \\
\hline
\end{tabular}

\section{Study Data}

To determine the number of lamps used at the Cumhuriyet University, current lamps were counted. After the counting, the number and types of the lamps, the number and types of the luminaires in each room and building were determined. As is seen in Table 3, the number of T8 and T12 lamps differs from one building to another. These are $18 \mathrm{~W}$ and 36W lamps and their lengths are $0.6 \mathrm{~m}$ and $1.2 \mathrm{~m}$, respectively. The number of all lamps in all buildings of the university was determined to be 32,700. If current lamps are replaced with T8 and T5 lamps, the number of lamps will remain the same, but if they are replaced with LED T8 lamps, the number of lamps is to be increased to produce the same light intensity. In case the LED T8 lighting system is used, the number of lamps and luminaires needed is shown in Table 4. 
Energy saving provides also a significant reduction in common emissions such as $\mathrm{CO}_{2}$, $\mathrm{NO}_{\mathrm{X}}, \mathrm{SO}_{2}, \mathrm{CO}$. Coal is used as the main fuel for power generation in Turkey. For emission calculations, the amount of $\mathrm{CO}_{2}, \mathrm{NO}_{\mathrm{X}}, \mathrm{SO}_{2}, \mathrm{CO}$ in the production of $1 \mathrm{kWh}$ electricity is taken as $1.02 \mathrm{~kg}, 0.00211 \mathrm{~kg}, 0.00784 \mathrm{~kg}$ and $0.00067 \mathrm{~kg}$, respectively [11].

Table 4 Total number of lamps and additional number of fixtures for T8 LED lamps

\begin{tabular}{cc|c}
\hline Watt & Number of lamps & Additional number of fixtures \\
\hline $9 \mathrm{~W}$ & 15,844 & 3,228 \\
$18 \mathrm{~W}$ & 48,807 & 12,748 \\
Total & 64,651 & 15,976 \\
\hline
\end{tabular}

\section{Life Cycle Cost Analysis}

Total energy consumption in the lighting system $\left(\mathrm{C}_{\mathrm{A}}\right)$ is calculated by using the following equation [4]:

$$
C_{A}=(L x W \times H) / 1000
$$

$L$ is the number of lamps, $W$ is the power and $H$ is the number of hours of use.

Energy saving $\left(\mathrm{S}_{\mathrm{E}}\right)$ is the difference between energy consumption of the current system $\left(\mathrm{C}_{\mathrm{A}}\right.$, Current $)$ and the prospective lighting system $\left(\mathrm{C}_{\mathrm{A}}\right.$, Prospective $)$, and is shown in the following equation [2]:

$$
S_{E}=C_{A, \text { current }}-C_{A, \text { prospective }}
$$

Bill saving $\left(\mathrm{S}_{\mathrm{B}}\right)$ is calculated by the following equation [2]. $\mathrm{S}_{\mathrm{E}}$ is the energy saved and $\mathrm{T}_{\mathrm{E}}$ is the electricity tariff. In the calculations, it was predicted that the electricity tariff would increase by about $8 \%$ each year.

$$
S_{B}=T_{E} \times S_{E}
$$

Operating cost $\left(C_{O}\right)$ is calculated by the following equation [2]:

$$
C_{o}=L \times W \times H \times T_{E}
$$
$[10]$.

Present worth factor (PW) is a method of determining the current value of future costs

$$
P W=\frac{(1+r)^{N}-1}{r(1+r)^{N}}
$$

where $\mathrm{r}$ is the inflation rate and $N$ is the lifetime. Payback period $(P P)$ is calculated by using the following equation [2]:

$$
P P=-\frac{\Delta P C}{\Delta O C}
$$

$P C$ is the investment cost and $O C$ is the yearly operation cost [2].

$L C C$ is calculated by the following equation [2]:

$$
L C C=C_{P}+(P W)\left(C_{O}\right)
$$

$C_{p}$ is the investment cost and $C_{O}$ is the increased annual operating cost.

\section{Results}

In the calculations, the single rate electricity tariff of $0.117 \$ / \mathrm{kWh}$ for 2017 [12] was used as a base, and the electricity tariff was expected to increase by $8 \%$ per year. The rate of 
increase in electricity tariff was calculated based on the changes in electricity prices in the period of ten years [12].

To calculate energy savings as a result of reduction in energy consumption due to the use of efficient lighting systems in the buildings, the average daily working time was taken as 8 hours for 5 days a week. It is planned to replace $10 \%$ of lamps in the first year, and to complete the replacement of all old lamps with new lamps in 10 years. The current lighting system consumes $2,544,162 \mathrm{~kW}$ of energy per year. The total amount of energy consumed at the end of each year and the amount of savings after the current system is replaced with the energy efficient lighting system are shown in Table 5.

In the first option, energy consumption will be reduced by about $18.9 \%$ when the current system is replaced with the T8-18W and T8-36W lighting system with electronic ballasts. Of the three options, the second one, in which the T5 system is used, will yield the greatest decrease in energy consumption. Energy consumption is reduced by $40.5 \%$ compared to the current system because T5 lamps provide the same amount of light intensity as the existing lighting system but use less power (Figure 3 ).

Table 5 Energy consumption for existing and new lighting systems

\begin{tabular}{|c|c|c|c|c|c|c|c|}
\hline \multirow{2}{*}{ Year } & \multicolumn{4}{|c|}{ Energy consumption for lighting systems $(\mathrm{kW})$} & \multicolumn{3}{|c|}{ Bill savings (\$) } \\
\hline & $\begin{array}{l}\text { Existing } \\
\text { System }\end{array}$ & $\begin{array}{c}\text { T8 } \\
\text { Electronic }\end{array}$ & T5 & T8 LED & $\begin{array}{c}\text { T8 } \\
\text { Electronic }\end{array}$ & T5 & $\begin{array}{c}\text { T8 } \\
\text { LED }\end{array}$ \\
\hline 2017 & $2,544,162$ & $2,544,162$ & $2,544,162$ & $2,544,162$ & 0 & 0 & 0 \\
\hline 2018 & $2,544,162$ & $2,496,051$ & $2,441,200$ & $2,502,140$ & 6,062 & 12,973 & 5,295 \\
\hline 2019 & $2,544,162$ & $2,447,939$ & $2,338,237$ & $2,460,117$ & 13,094 & 28,022 & 11,437 \\
\hline 2020 & $2,544,162$ & $2,399,827$ & $2,235,275$ & $2,418,094$ & 21,213 & 45,396 & 18,528 \\
\hline 2021 & $2,544,162$ & $2,351,715$ & $2,132,312$ & $2,376,071$ & 30,546 & 65,370 & 26,680 \\
\hline 2022 & $2,544,162$ & $2,303,603$ & $2,029,350$ & $2,334,048$ & 41,237 & 88,250 & 36,018 \\
\hline 2023 & $2,544,162$ & $2,255,491$ & $1,926,387$ & $2,292,025$ & 53,443 & 114,372 & 46,680 \\
\hline 2024 & $2,544,162$ & $2,207,379$ & $1,823,425$ & $2,250,002$ & 67,339 & 144,109 & 58,816 \\
\hline 2025 & $2,544,162$ & $2,159,268$ & $1,720,462$ & $2,207,979$ & 83,115 & 177,871 & 72,596 \\
\hline 2026 & $2,544,162$ & $2,111,156$ & $1,617,500$ & $2,165,957$ & 100,985 & 216,114 & 88,204 \\
\hline 2027 & $2,544,162$ & $2,063,044$ & $1,514,537$ & $2,123,934$ & 121,182 & 259,336 & 105,845 \\
\hline TOTAL & $27,985,786$ & $25,339,634$ & $22,322,849$ & $25,674,529$ & 538,216 & $1,151,813$ & 470,099 \\
\hline
\end{tabular}

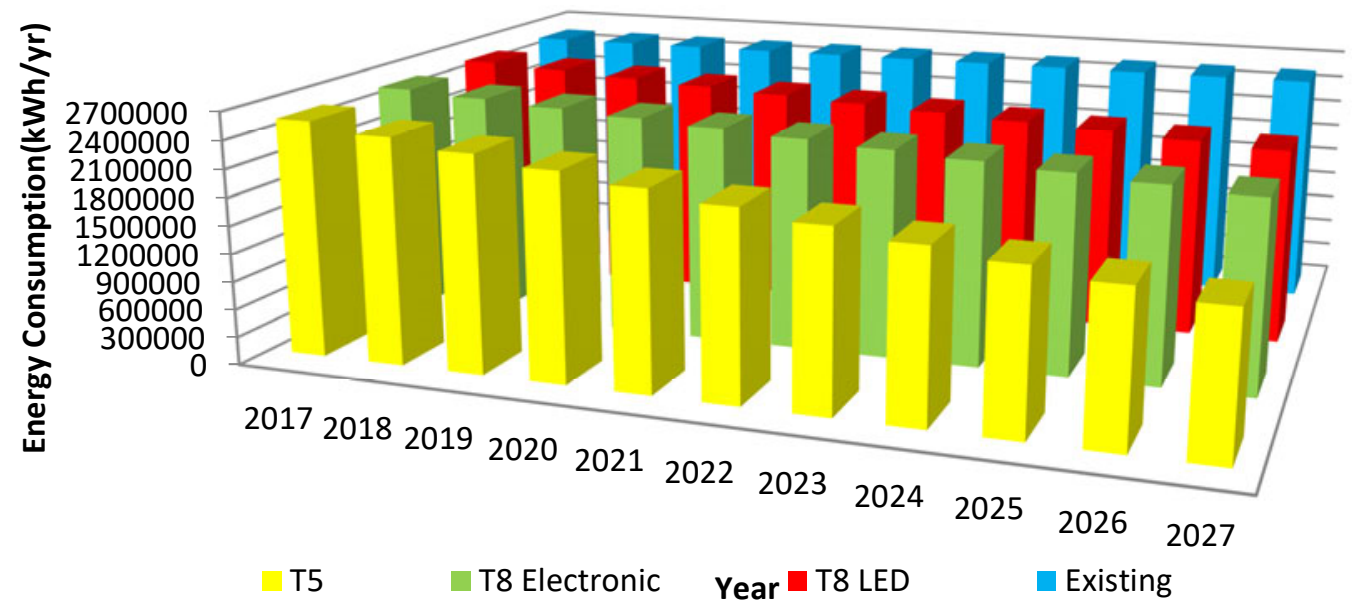

Fig. 3 Comparison of energy consumption of standard and new lighting systems

In the third option, in which T8 LED lamps are used, the power consumption is low, but because their lumen value is low, the number of lamps and luminaires in the system is high. Compared with the current system, energy consumption is reduced by $16.5 \%$ in the third option. The comparison of the amount of savings in payments revealed that the T5 lighting 
system is the most economical lighting system with the cost of $\$ 1,151,813$. Savings in the case of the T8 electronic and T8 LED systems are close to each other and estimated to be $\$ 538,216$ and $\$ 470,009$, respectively. Mahlia et al. carried out lighting retrofits of buildings and found that $12 \%$ and $45 \%$ less energy can be consumed by replacing the building lighting with a T5 fluorescent lighting system. The change in payback periods and LCC over time is shown in Figure 4, Figure 5 and Table 6.

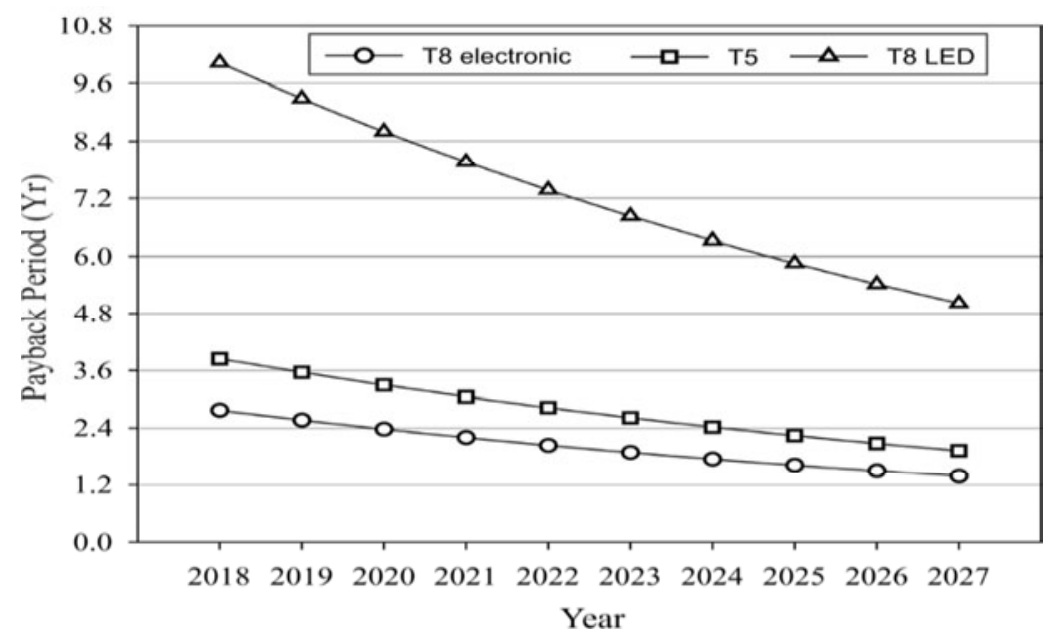

Fig. 4 Change in payback periods over time for different lighting systems

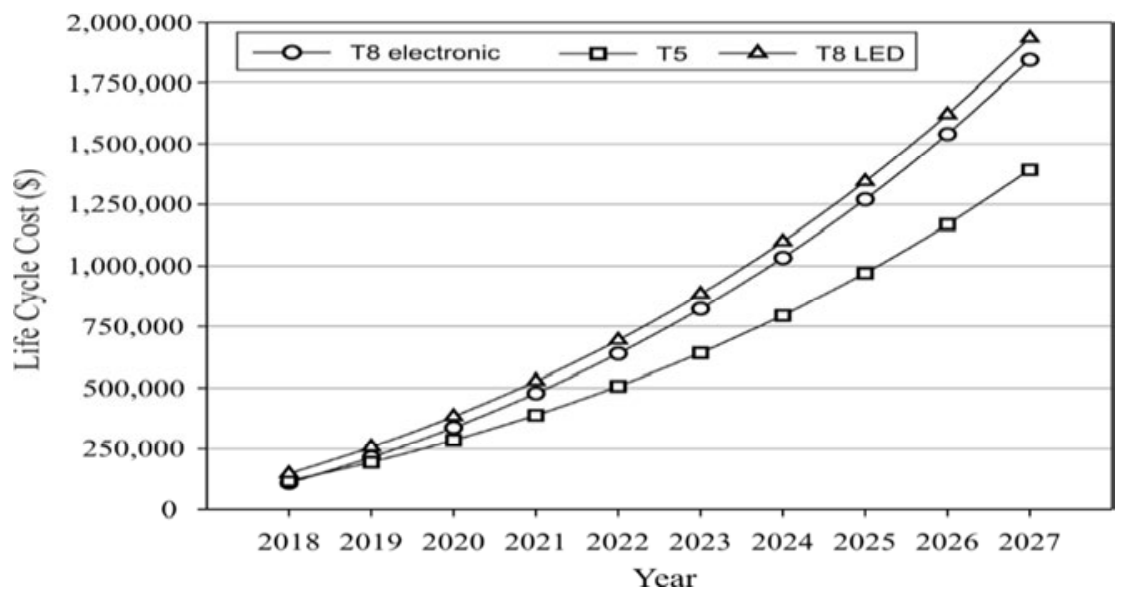

Fig. 5 Change in LCC over time for different lighting systems

Table 6 Change in payback period and LCC for different lighting systems

\begin{tabular}{rcrcrrr}
\hline Year & \multicolumn{2}{c}{ T8 } & \multicolumn{2}{c}{ T5 } & \multicolumn{2}{c}{ T8 LED } \\
\hline & $\begin{array}{c}\text { Payback } \\
\text { Period (year) }\end{array}$ & LCC (\$) & $\begin{array}{c}\text { Payback } \\
\text { Period (year) }\end{array}$ & LCC (\$) & $\begin{array}{c}\text { Payback } \\
\text { Period (year) }\end{array}$ & LCC (\$) \\
\hline 2017 & 0 & 0 & 0 & 0 & 0 & 0 \\
2018 & 2.77 & 108,256 & 3.85 & 117,022 & 10.03 & 147,259 \\
2019 & 2.57 & 214,336 & 3.56 & 194,898 & 9.29 & 256,470 \\
2020 & 2.38 & 336,803 & 3.30 & 284,804 & 8.60 & 382,552 \\
2021 & 2.20 & 477,601 & 3.05 & 388,168 & 7.96 & 527,506 \\
2022 & 2.04 & 638,879 & 2.83 & 506,566 & 7.37 & 693,543 \\
2023 & 1.89 & 823,012 & 2.62 & 641,743 & 6.83 & 883,111 \\
2024 & 1.75 & $1,032,625$ & 2.42 & 795,626 & 6.32 & $1,098,911$ \\
2025 & 1.62 & $1,270,616$ & 2.24 & 970,342 & 5.85 & $1,343,926$ \\
2026 & 1.50 & $1,540,185$ & 2.08 & $1,168,240$ & 5.42 & $1,621,451$ \\
2027 & 1.39 & $1,844,860$ & 1.92 & $1,391,911$ & 5.02 & $1,935,119$ \\
\hline
\end{tabular}


In all the three systems, while payback periods decrease over time, LCCs increase. After all lamps are replaced, the payback periods are 1.39 years in the case of the T8 electronic system, 1.92 years in the case of the T5 system and 5.02 years in the case of the T8 LED system. The Life Cycle Cost (LCC) includes operating, equipment and maintenance costs. The present worth (present value) factor used in the calculations was 3.518. The highest LCC in the current system is in the amount of $\$ 2,260,809$. With the use of the T8 electronic lighting system, the LCC drops to $\$ 1,844,860$, which corresponds to an $18.4 \%$ decrease. If the current system is completely replaced with the $\mathrm{T} 5$ system, which is the second option, the LCC drops to $\$ 1,391,911$, which corresponds to a $38.4 \%$ decrease. The life cycle cost for the T8 LED system is $\$ 1,935,119$, which is about $14.4 \%$ less than that of the current system. As is seen in the LCC analysis, the lowest cost is achieved with the T5 lighting system.

The changes in $\mathrm{CO}_{2}, \mathrm{NO}_{\mathrm{X}}, \mathrm{SO}_{2}, \mathrm{CO}$ emission values over the years for the current lighting system in the buildings of the Cumhuriyet University and for all the proposed lighting systems are shown in Figure 6. As is seen in Figure 6, with the installation of all new lighting systems, all emissions will be reduced, and the emission values in the T8 electronic and T8 LED lighting systems are close to each other. With the installation of the T5 system, $\mathrm{CO}_{2}$, $\mathrm{NO}_{\mathrm{X}}, \mathrm{SO}_{2}$, and $\mathrm{CO}$ emissions will decrease by 1,050 tons, 2.17 tons, 8.07 tons and $690 \mathrm{~kg}$, respectively by the end of 2027.
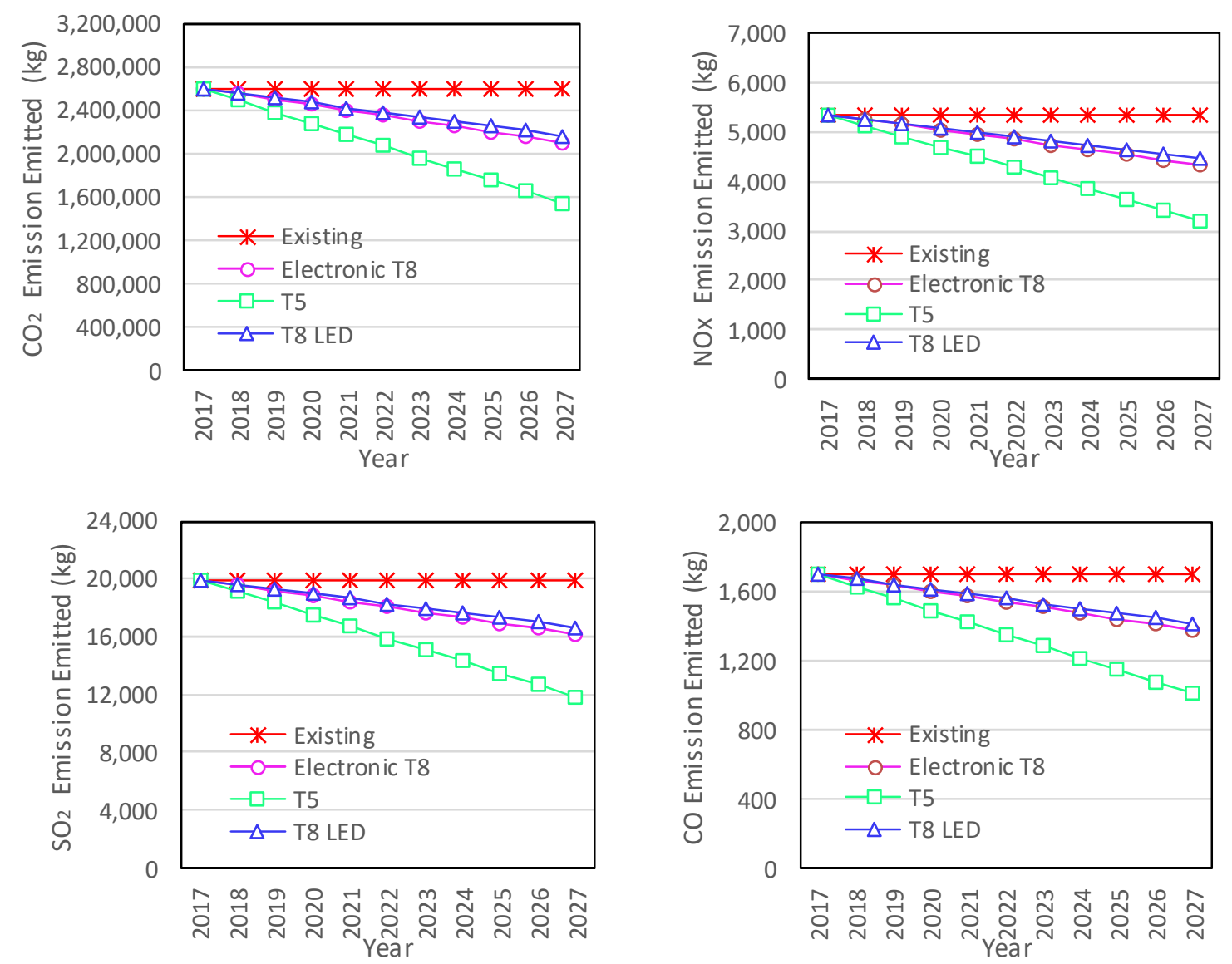

Fig. 6 Changes in $\mathrm{CO}_{2}, \mathrm{NO}_{\mathrm{X}}, \mathrm{SO}_{2}, \mathrm{CO}$ emission values over the years for different lighting systems

\section{Conclusions}

In the present study, the reduction in electricity consumption, the amount of savings, the payback period and the environmental impacts have been investigated in case the current lighting system at the Cumhuriyet University is replaced with different energy efficient lighting 
systems. T8 electronic, T5 and T8 LED lighting systems were considered as alternative efficient lighting systems. The result of the calculations revealed that the use of efficient lighting systems would reduce energy consumption by between $16.5 \%$ and $40.5 \%$. The minimum energy consumption would be achieved with the installation of the T5 system. As seen in the LCC analysis, the lowest and maximum costs are achieved with the T5 and T8 LED lighting systems. The payback period of the T8 LED lighting system is four times the payback period of the T8 electronic and T5 systems. The comparison of the T8 electronic lighting system with the T5 lighting system showed that the LCC and the electricity consumption values were high and the payback period was low in the former system. The comparison of the T5 system with the T8 LED system indicated that in the T8 LED system, the initial investment costs would increase due to the use of additional lamps. Therefore, the T5 system is more advantageous due to its low electricity consumption resulting in the low LCC. The least amount of $\mathrm{CO}_{2}, \mathrm{NO}_{\mathrm{X}}, \mathrm{SO}_{2}, \mathrm{CO}$ emissions is achieved with the use of the T5 lighting system.

\section{REFERENCES}

[1] Turkey Electricity Transmission Company General Directorate Planning and Strategic Management Department Presidency 10 years (2017-2026) Demand Forecasts Report, Page 56.

[2] Mahlia, T. M. I.; Razak, H. A. Nursahida, M. A. Life cycle cost analysis and payback period of lighting retrofit at the University of Malaya, Renewable and Sustainable Energy Reviews, 2011, 15.2: 1125-1132. https://doi.org/10.1016/j.rser.2010.10.014.

[3] Reber, A.; Erhart, D. K. An efficient retrofitting approach for improving lighting solutions: A case study at Stuttgart University of Applied Sciences. Stuttgart, Germany

[4] Di Stefano, J.; Energy efficiency and the environment: the potential for energy efficient lighting to save energy and reduce carbon dioxide emissions at Melbourne University, Australia, Energy, 2000, 25.9: 823839. https://doi.org/10.1016/S0360-5442(00)00015-3.

[5] Jamaludin, A. A.; Mahmood, N. Z.; Ilham, Z. Performance of electricity usage at residential college buildings in the University of Malaya campus, Energy for Sustainable Development, 2017, 40: 85-102. https://doi.org/10.1016/j.esd.2017.07.005.

[6] Lam, J. C.; Chan, W. W. Life cycle and green cost analysis of energy-efficient lighting for hotels. Architectural Science Review, 2001, 44.2: 135-138. https://doi.org/10.1080/00038628.2001.9697463.

[7] Preston, D.J.; Woodbury, K. A. Cost-benefit analysis of retrofit of high-intensity discharge factory lighting with energy-saving alternatives, Energy Efficiency, 2013, 6.2: 255-269. https://doi.org/10.1007/s12053-012-9179-1.

[8] Soori, P. K.; Vishwas, M. Lighting control strategy for energy efficient office lighting system design, Energy and Buildings, 2013, 66: 329-337. https://doi.org/10.1016/j.enbuild.2013.07.039.

[9] Stansbury, J.; Mittelsdorf, A. M. Economic and environmental analysis of retrofitting a large office building with energy-efficient lighting systems. Environmental Management, 2001, 27.6: 909-918. https://doi.org/10.1007/s002670010.

[10] Fertelli, A. Determination of optimum insulation thickness for different building walls in Turkey, Transactions of Famena, 2013, 37.2: 103-113.

[11] Atilgan, B.; Azapagic A. Life cycle environmental impacts of electricity from fossil fuels in TURKEY, Journal of Cleaner Production, 2015, 106: 555-564. https://doi.org/10.1016/j.jclepro.2014.07.046.

[12] Republic of Turkey Energy Market Regulatory Authority, 2017, https://www.epdk.org.tr/Detay/Icerik/3100/elektrik-faturalarina-esas-tarife-tablolari.

Submitted: $\quad 10.11 .2017$

Accepted: $\quad 11.10 .2018$
Assoc. Prof. Ahmet Fertelli

Department of Mechanical Engineering,

Cumhuriyet University Faculty of

Engineering, Sivas, Turkey

Mehmet Balta

Technical Sciences of Vocational School, Machine Program Amasya University, Amasya, Turkey 